\title{
OBSERVATIONS ON PULMONARY CIRCULATION DURING LIGHT ETHER ANAESTHESIA IN MAN*
}

\author{
Gordon M. WYANT, F.F.A.R.C.s., HARry V. DONALdSON, M.D., \\ AND JOHN E. MF.RRIMAN, F.R.C.P.(C) $\dagger$
}

InVESTIGATIONS carried out during recent years have shed increasing light on the peripheral cardiovascular and respiratory effects of anaesthetic agents and techniques. By comparison much less information is available on the role of the pulmonary circulation in human haemodynamics and the effect of anaesthesia upon it.

Until Cournand proved the ease and efficacy of cardiac catheterization, no method was available for the study of the lesser circulation that could be readily and safely applied in man. Many workers have stressed the importance of the pulmonary circulation in human haemodynamics but their conclusions have been based on either animal expèriments or deductions from observations of the systemic circulation.

Johnson's study $y^{1}$ of the effect of various anaesthetic techniques on the total circulatory system and on respiration was a monumental piece bf work. He demonstrated for the first time by direct methods the importance of the lesser circulation and the role of the lung as an important blood depoto in man. His studies were made on surgical patients of both sexes in whom age, height, and weight varied greatly, however, and some of whom suffered from cardiorespiratory disability.

Sancetta and Lynn's work ${ }^{2,3}$ on spinal anaesthesia was excellent in that the subjects were given no vasopressors and they did not undergo operation. This may explain some of the minor differences in results of their work from that of Johnson. Li and Etsten investigated the haemodynamic effects of cl clopropane and found that pulmonary artery pressure rose during, anaesthesia.

In the course of some previous studies of the cardiovascular effects of halothane and of the azeotropic mixture of halothane and ether, ${ }^{5}{ }^{6}$ it had been observed that, as anaesthesia progressed, there was an increase in pulmonary artery pressure and an even more pronounced rise in total pulmonary resistance. Because of a number of variables in this study, such as changing depth of anaesthesia and the use of a new anaesthetic agent of relatively poorly understood properties, it was decided to investigate this phenomenon further and attempt to elucidate what changes occurred in the pulmonary circulation under more controlled conditions of anaesthesia.

*Presented before the Second World Congress of Anaesthesiologists, September 4-10, 1960, Toronto, Ontario.

†From the Departments of Anaesthesia and Medicine (Cardio-pulmonary Service), University of Saskatchew an and University Hospital, Saskatown, Saskatchewan. 


\section{METHOD}

Experiments were carried out on 16 healthy male volunteers between the ages of 21 and 30 years. They weighed between 140 and $190 \mathrm{lb}$. with a mean body surface area of 1.8 square meters. The men were instructed not to have breakfast on the day of the experiment. No medication other than intravenous atropine sulphate was administered. This was given because the study was to be undertaken under light ether anaesthesia and excessive salivation had to be prevented. A cardiac catheter was passed under fluoroscopic control from the left median antecubital vein in to the pulmonary artery. An 18 gáuge Cournand needle was inserted into the left femoral artery. Electrocardiographic and electroencephalographic leads were applied.

\section{Cardiac Output}

Cardiac output was determined by the indicator-dilution technique using the intravenous injection of Cardio-green with arterial sampling through a cuvette oximeter. Ftis method has been described previously in detail. ${ }^{7}$

\section{Peripheral Artery Pressure}

By means of the indwelling arterial needle, continuous arterial pressure tracings were recorded. The intra-arterial needle was connected by a polyethylene catheter to a Statham strain gauge and hence to a multi-channel photographic recorder which allowed continuous monitoring and |recording of these pressures.

\section{Pulmonary Artery Pressure}

The same recording apparatus was used for pulmonary artery pressure as for the peripheral artery pressure; by connecting the cardiac catheter in a similar manner to a strain gauge.

\section{Electrocardiogram}

A third channel of the recorder was ussèd for the continuous monitoring and recording of the electrocardiogram.

\section{Electroencephalogram}

Tracings were taken at intervals during the experiments on an Edin Anesthograph in order to maintain the depth of ether anaesthesia as nearly constant as possible.

\section{Airway Pressure}

Through a special adaptor on the endotracheal connector, a small polyethylene tube was inserted into the airway through the lumen of the endotracheal tube and was connected to a Statham transducer which then allowed airway pressure to be recorded on another channel of the recorder. 


\section{Total Peripheral Resistance}

This was calculated according to the standard formula:

$$
R=\frac{B A(F A)_{m}-O}{C O} \times 1332
$$

where $R$ equals the total peripheral resistance in dynes $/ \mathrm{sec} . / \mathrm{cm} .^{-5}, B A(M)$ or $F A(M)$ is brachial or femoral arterial mean pressure in mm. of mercury, $\mathrm{CO}$ represents cardiac output in ml. per sec., $O$ is an approximation of the left ventricular end-diastolic pressure, and 1332 is a figure for the conversion of pressure to dynes.

\section{Total Pulmonary Resistance}

This was calculated by using the same formula, substituting pulmonary mean arterial pressure in ml. of mercury for femo-al mean artery pressure.

\section{Mean Transit Time}

This was calculated from the formula:

$$
\text { M.T.T. }=\frac{\Sigma c t}{\Sigma c}
$$

$c$ being the concentration of the dye and $t$ being time in sec.

\section{Central Blood Volume}

This was calculated according to the formula: "Cardiac output in L./min. $X$ mean transit time/min."

\section{Stroke Volume}

Stroke volume was obtained by dividing the calculated cardiac output by the pulse rate which was available from the electrocardiơgraphic tracing.

Control values were recorded over a period of not less than $10 \mathrm{~min}$. and until at least two control cardiac output measurements closely similar to one another were obtained. Anaesthesia was then induced with 2.5 per cent sodium thiopental. This was followed by a dose of succinylcholine and, following inflation of the lungs with oxygen, the throat, larynx, and trachea were sprayed with up to $2 \mathrm{ml}$. of 4 per cent lidocaine. A No. 9 Magill cuffed endotracheal tube was then passed and this was connected to a Heidbrink anaesthesia machine. Anaesthesia was continued with a mixture of nitrous oxide $(4 \mathrm{~L}$.$) .$ oxygen $(2 \mathrm{~L}$.$) , and diethyl ether. Clinically, the level of anaesthesia was the$ lightest consistent with smooth anaesthesia and with tolerance of the endotracheal tube. As soon as anaesthesia had become stabilized, the endotracheal polyethylene catheter was connected to the pressure transducer and measurements of airway pressure were started. It was assumed that the effect of thiopental had worn off when the blood pressure, following the postinduction drop, had become restabilized and the effect of succinylcholine was deemed to have worn off when adequate spontaneous ventilation had become re-established. 
After at least a further $10 \mathrm{~min}$. of stable anaesthesia on adequate spontaneous respiration, a cardiac output determination was made and systolic, diastolic, and mean pressures were recorded.

Following completion of thesc determinations, respiration was actively controlled by means of an Etsten hand ventilator which delivered predetermined tidal volumes. The rate was kept constant by the watch and pressures of inflation were maintained by observing the pressure dial on the machine and also the airway pressure recording on the oscilloscope. Care was taken that the airway prèssure returned to base-line during the expiratory pause (Fig. 1).

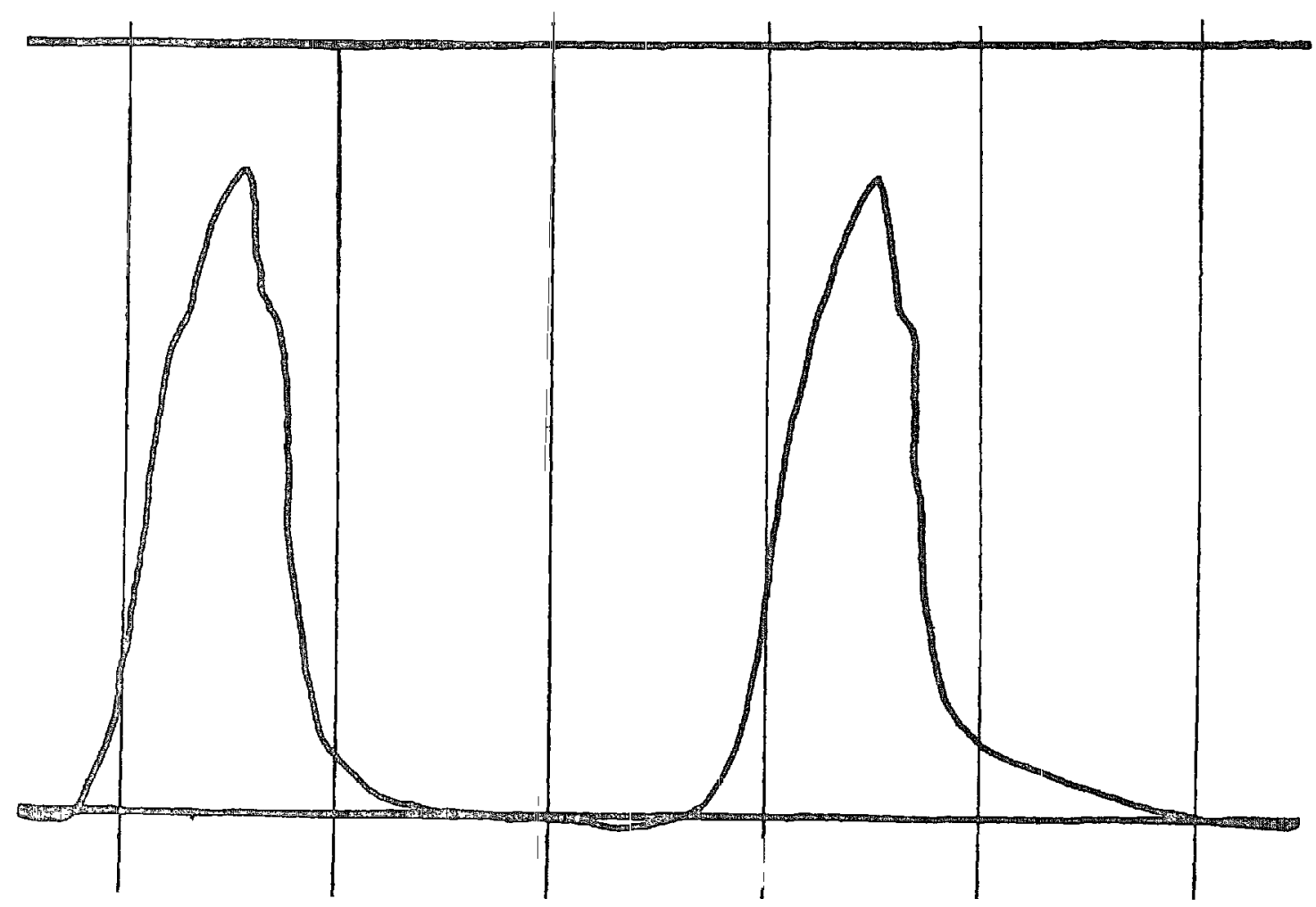

FIGLRE 1. Typical airway pressure tracing during controlled respiration with Etsten Ventilator. Base-line: $\mathrm{O} \mathrm{mm} . / \mathrm{Hg}$; top-line: $10 \mathrm{~mm} . / \mathrm{Hg}$; interval between vertical lines: 1 sec.

Non-rebreathing valves only were used. The amount of ether was adjusted to maintain a level of anaesthesia comparable with the one observed during spontaneous respiration. At the end of 10 min., a cardiac output determination was made once more. All means were determined and various other parameters recorded.

\section{Other Determinations}

Arterial oxygen percent saturation, $\mathrm{PaCO}_{2}$, and $\mathrm{pH}$ were done simultaneously with each cardiac output determination during the first 6 experiments.

In addition to the above 16 experiments, 7 more were done following the same method but intubation was deferred until readings had been obtained on stable anaesthesia with a face mask. At the time of each cardiac output determination, an attempt was made to measure the "pulmonary capillary" pressure by wedging the cardiac catheter in a small branch of a pulmonary artery. Pressures obtained were not used in aplalysis unless the pressure 
could be verified as being a true wedge pressure. The following criteria were met in each case: (i) an atrial tye pressure tracing; (ii) lower mean pressure than the mean pulmonary artery pressure; (iii) a sudden unwedging on withdrawal of the catheter; (iv) 100 per cent saturation of a blood sample taken from the site of the catheter tip. Hellems, Haynes, and Dexter ${ }^{8}$ have shown that the verified "PC" pressure, meeting the criteria mentioned above, is a true reflection of the mean left auricular pressure. This measurement of "PC" pressure along with the measurements of mean pulmonary artery pressure and cardiac output allowed a partitioning of the total pulmonary resistance into that owing to the pulmonary vascular resistance and that owing to the resistance caused by the left heart.

In a further 3 cases, anaesthesia was maintained with nitrous oxide-oxygenthiopental drip for purposes of comparison.

In order to exclude mechanical resistance as influencing results several of the subjects, while awake and resting, were made to breathe through the anaesthetic circuit with the endotracheal connector as the mouthpiece and with a noseclip in place. This test was conducted for variable lengths of time while pulmonary pressures were monitored.

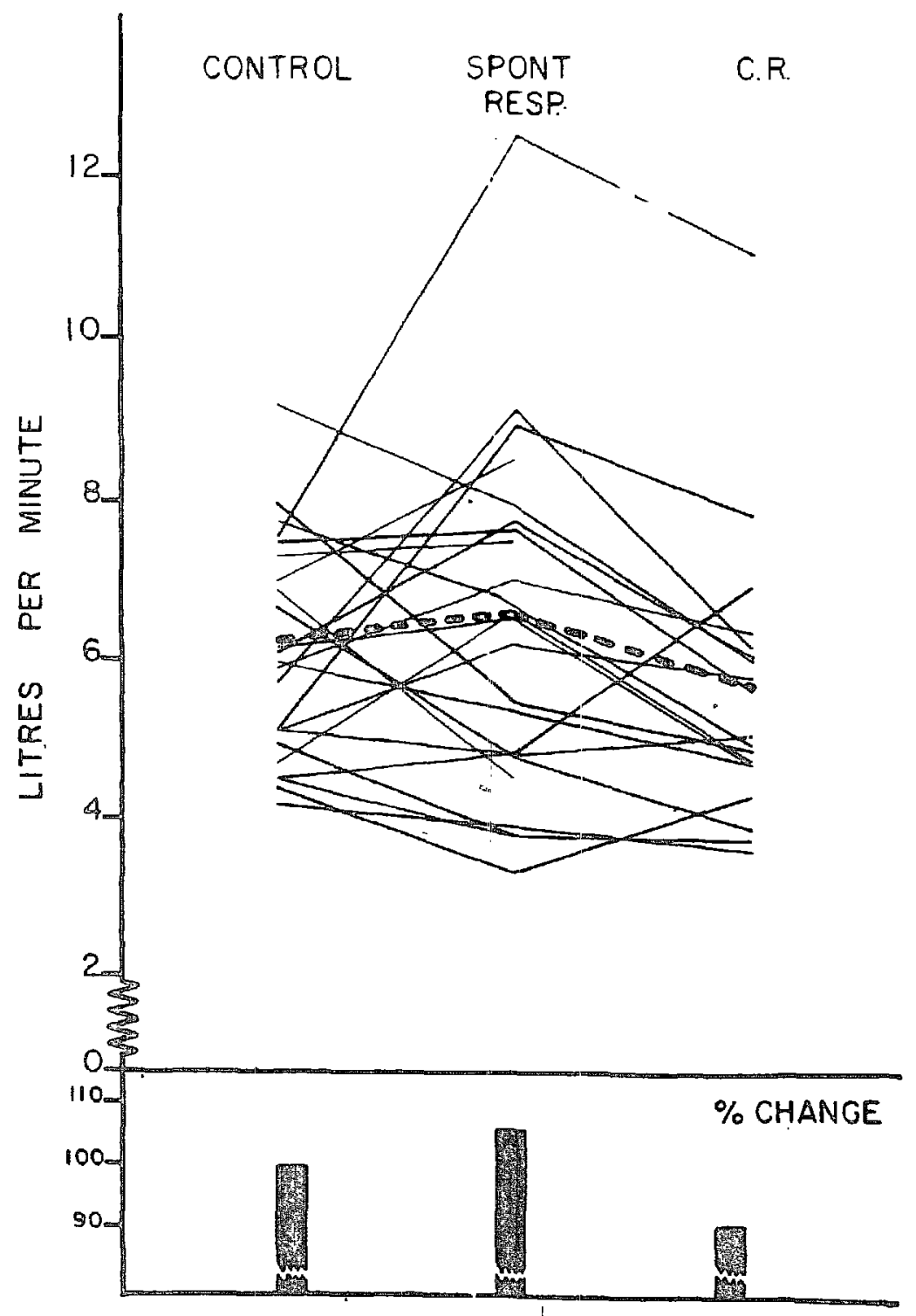

FIGURE 2. Cardiac Output: controlled respiration on Etsten Ventilator. 
A number of observations were made using a mechanical ventilator with different pressure curves. Since this part of the investigation is as yet incomplete, it will not be reported here.

\section{RESULTS}

\section{Cardiac Output (Figure Q)}

From observation of this figure, it is at once obvious that there was wide variation of the control cardiac output from individual to individual, each thin line representing a different volunteer. Calculation of the cardiac index did not narrow this scatter, the range being 1.98 to 6.63 with a mean of 4.08 .

The response of cardiac output depends upon the depth of anaesthesia, the agent used, and the mean airway pressure.4, $9,10,11,12$ While in some cases in this study there was a considerable increase, analysis of the mean (broken line) revealed statistically insignificant changes in cardiac output. The bottom of the table shows the percentage changês after having assigned arbitrarily the value 100 per cent to all mean controls. This again revealed that the percentage changes are not significant. This is in agreement with Johnson's findings under light ether anaesthesia.

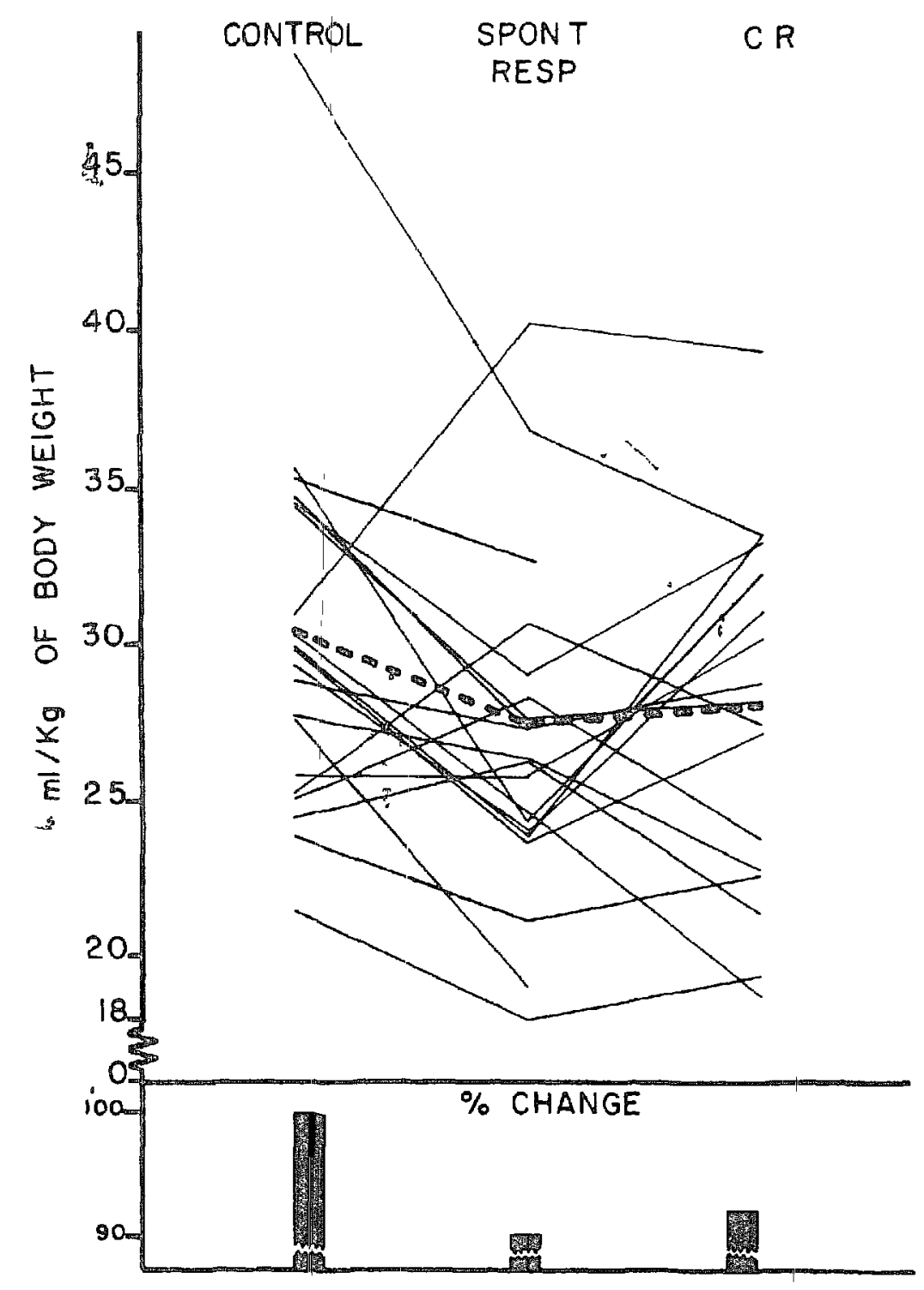

Figure 3. Central blood volume. 


\section{Central Blood Volume (Figure 3)}

The mean central blood volume followed closely upon the cardiac output or rather the output followed the central blood volume, except during spontaneous respiration. Here the decrease in central blood volume was significant, although cardiac output and stroke volume were not significantly altered.

\section{Mean Systemic Blood Pressure (Figure 4)}

This showed the same wide variation of control values as did the other parameters. After anaesthesia had become established, there was usually, but not invariably, a fall of mean systemic pressure with a tendency to some

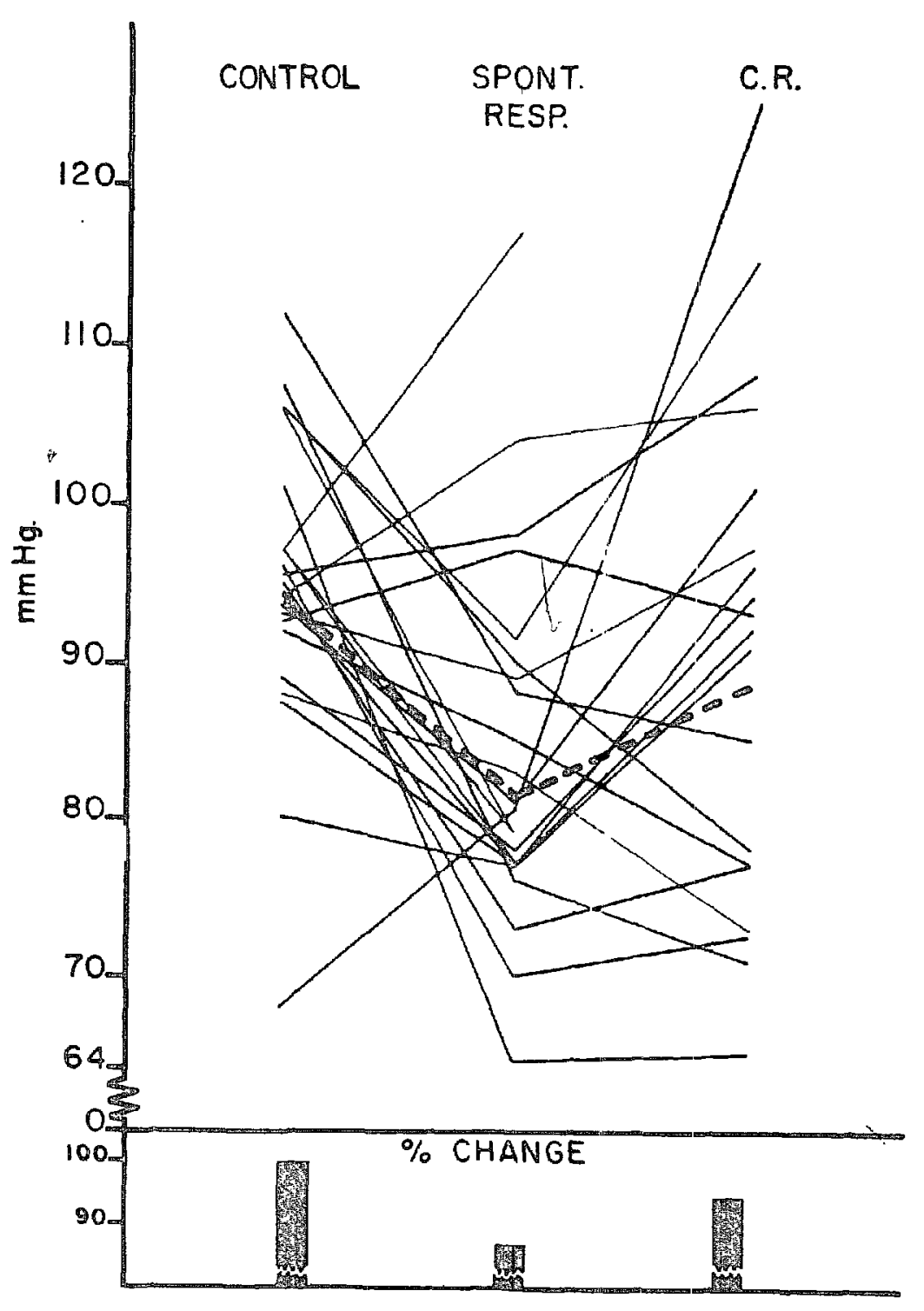

Figure 4. Mean systemic blood pressure.

recovery during controlled respiration. The mean (broken line) indicates a quite substantial fall in systemic pressure following establishment of anaesthesia and this difference is statistically significant. There tended to be partial recovery during controlled respiration. The fall in systemic pressure during anaesthesia is a well-known phenomenon. and has been previously described in the literature. Nevertheless, it was surprising to realize that this too did not occur invariably. It may be well to record that the subjects in whom the expected fall did not 
materialize are different individuals from those whose cardiac output increased rather than fell.

\section{Peripheral Resistance (Figure 5)}

No significant change was observed in the mean peripheral resistance and it must therefore be deduced that no marked vasodilatation occurs under light ether anaesthesia under the conditions of this experiment. Since there was

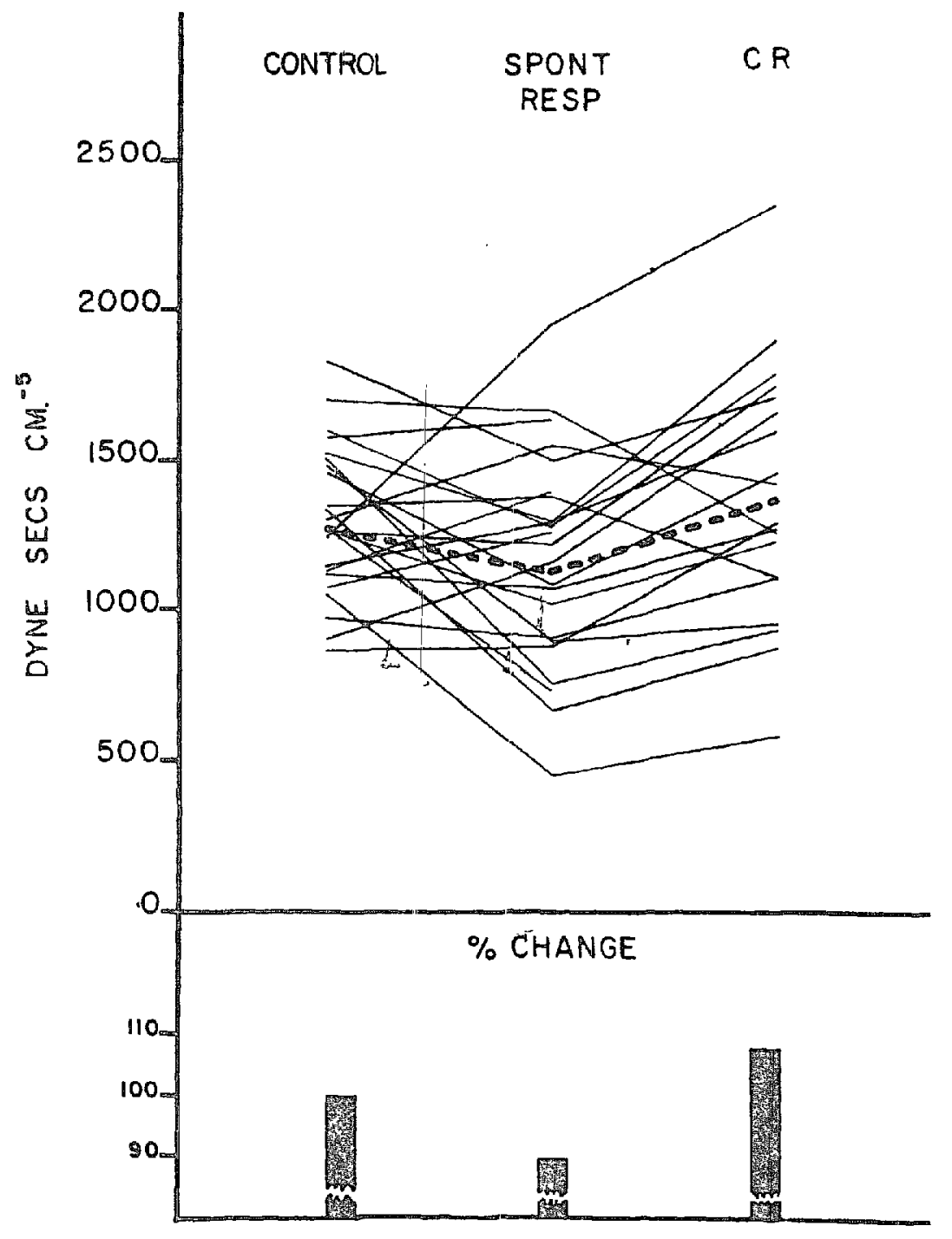

Frgure 5. Total peripheral resistance.

no significant drop in either cardiac output or total peripheral resistance, one would expect no significant change in mean systemic blood pressure, but this was not the case. The summation of the two has obviously produced a significant change in mean systemic blood pressure.

\section{Mean Transit Time (Figure 6)}

There was a speeding up of the circulation during spontaneous respiration under anaesthesia followed by slowing under controlled respiration. However, the changes were statistically not significant and therefore it may be said that anaesthesia of the depth used in these experiments does not significantly influence this parameter. It is interesting that, in all but six instances, 


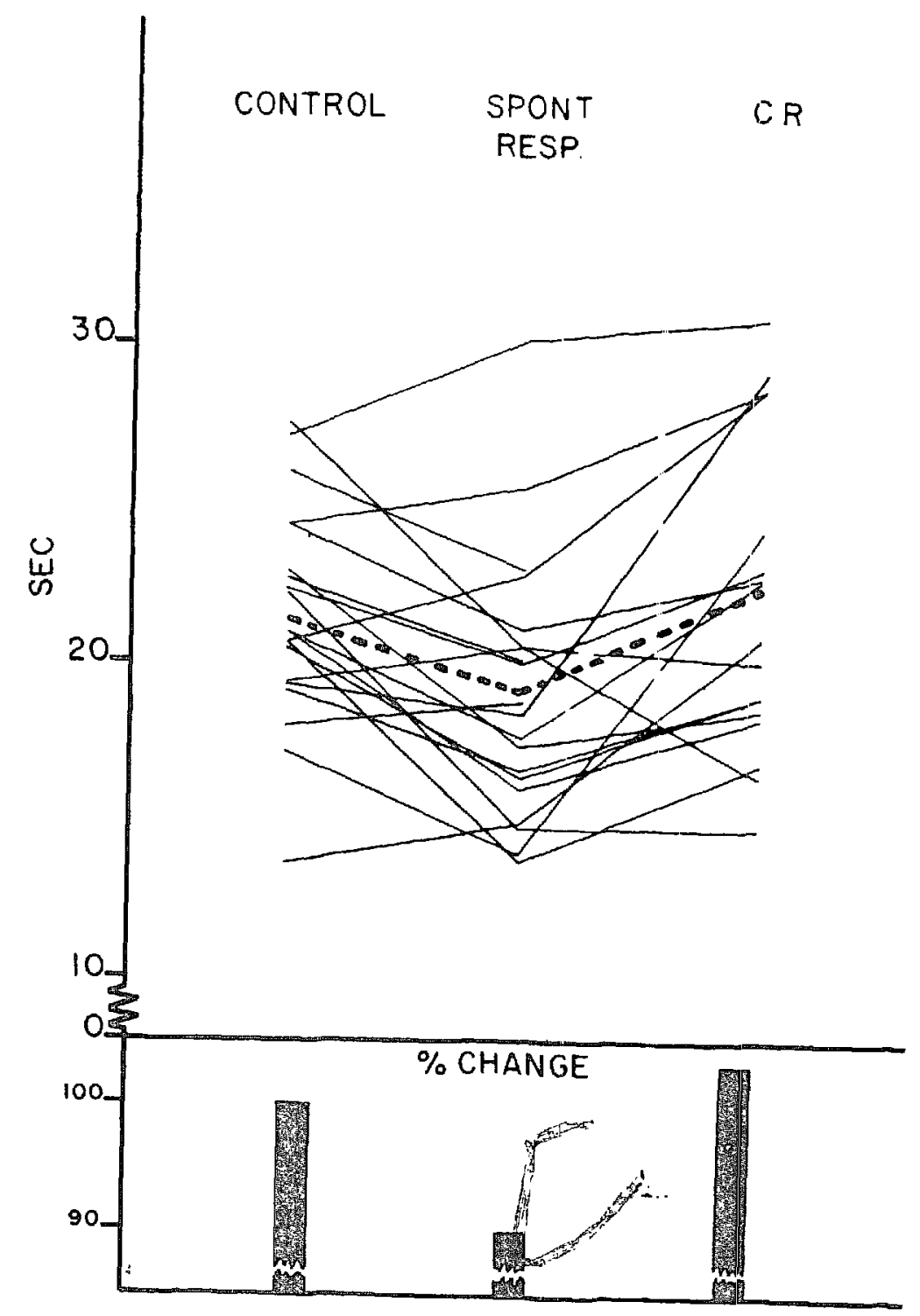

Figure 6. Mean transit time.

circulation time was actually somewhat shorter after the subject had been anaesthetized.

\section{Stroke Volume (Figure 7)}

Although the cardiac output was not significantly depressed or changed while under controlled respiration, the mean value for stroke output was significantly decreased. In other words, cardiac output was maintained by an increase in heart rate. In each individual case in: which the stroke output was decreased, there was a concomitant decrease in the calculated central blood volume.

\section{Mean Pulmonary Artery Blood Pressure (Figure 8)}

There was a relatively wide variation of mean pulmonary blood pressure in the controls. Under spontaneous respiration during ether anaesthesia there was a consistent rise in mean pulmonary artery pressure with the exception of two cases, while in the third no change occurred. As solon as respiration was manually controlled, a further rise in pulmonary artery pressure occurred in all but four instances. This was despite the fact that the system incorporated a non- 


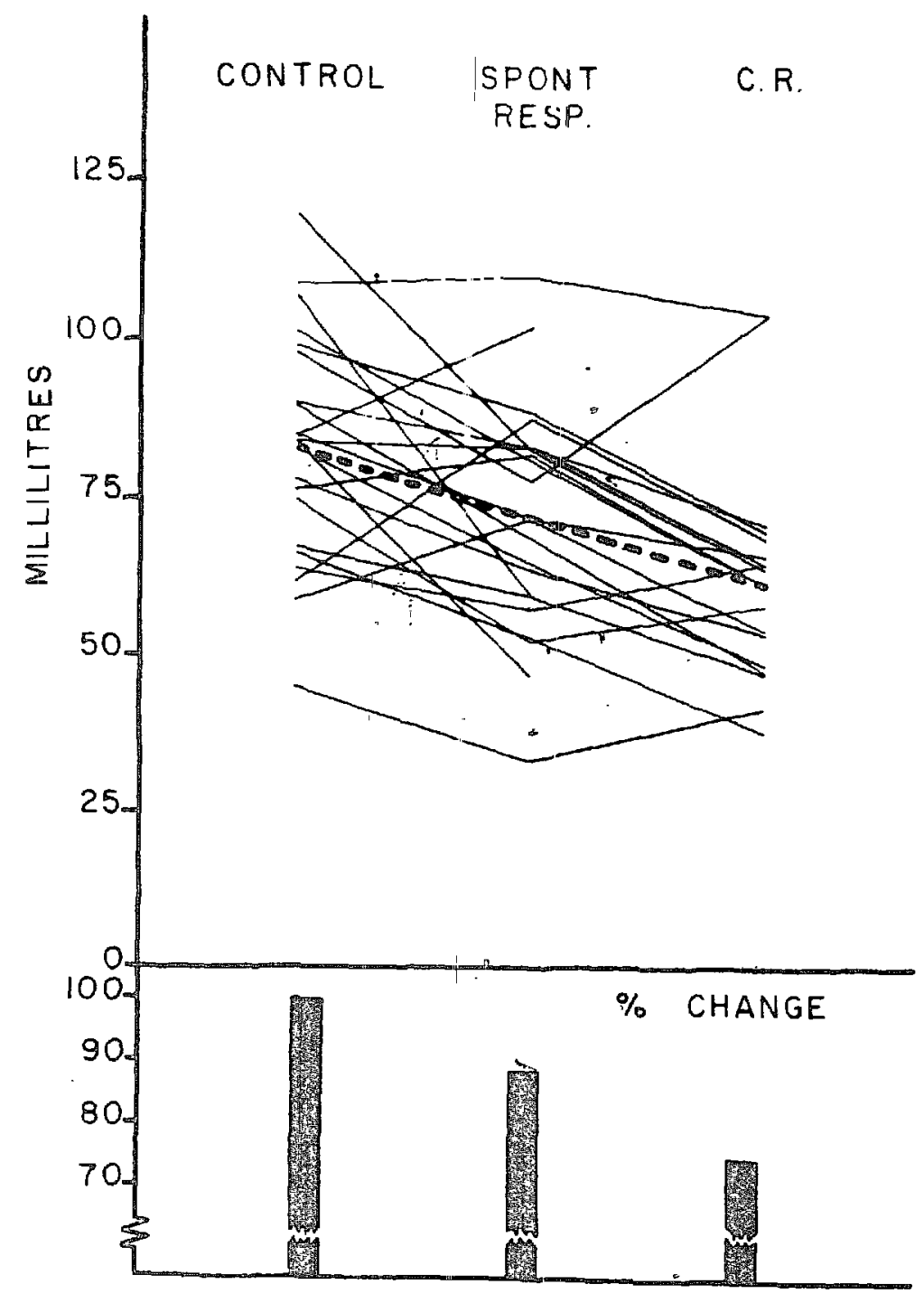

FIgURE 7. Strokè volume.

rebreathing valve and that great care was taken that respiration was slow with adequate expiratory pause and that the endotracheal pressure always returned to the zero baseline. There was thus no positive pressure maintained in the airway during the expiratory pause. The mean pulmonary pressures showed a very marked rise with spontaneous respiration as compared to the control and a further rise while contfolled respiration was carried out. These changes are statistically significant.

\section{Total Pulmonary Resisiance (Figure 9)}

The observations made during previous experiments were again confirmed. A significant and continuous rise of the total pulmonary resistance occurred, which increased with spontaneous respiration and further increased when respiration was controlled. It should be remembered at this point that one is dealing with total pulmonary resistance which represents not only the resistance across the pulmonary vascular bed but also the resistance to inflow of blood into the left heart. Therefore, it became imperative to determine which of the two components was primarily responsible for the rise in total pulmonary resistance. 


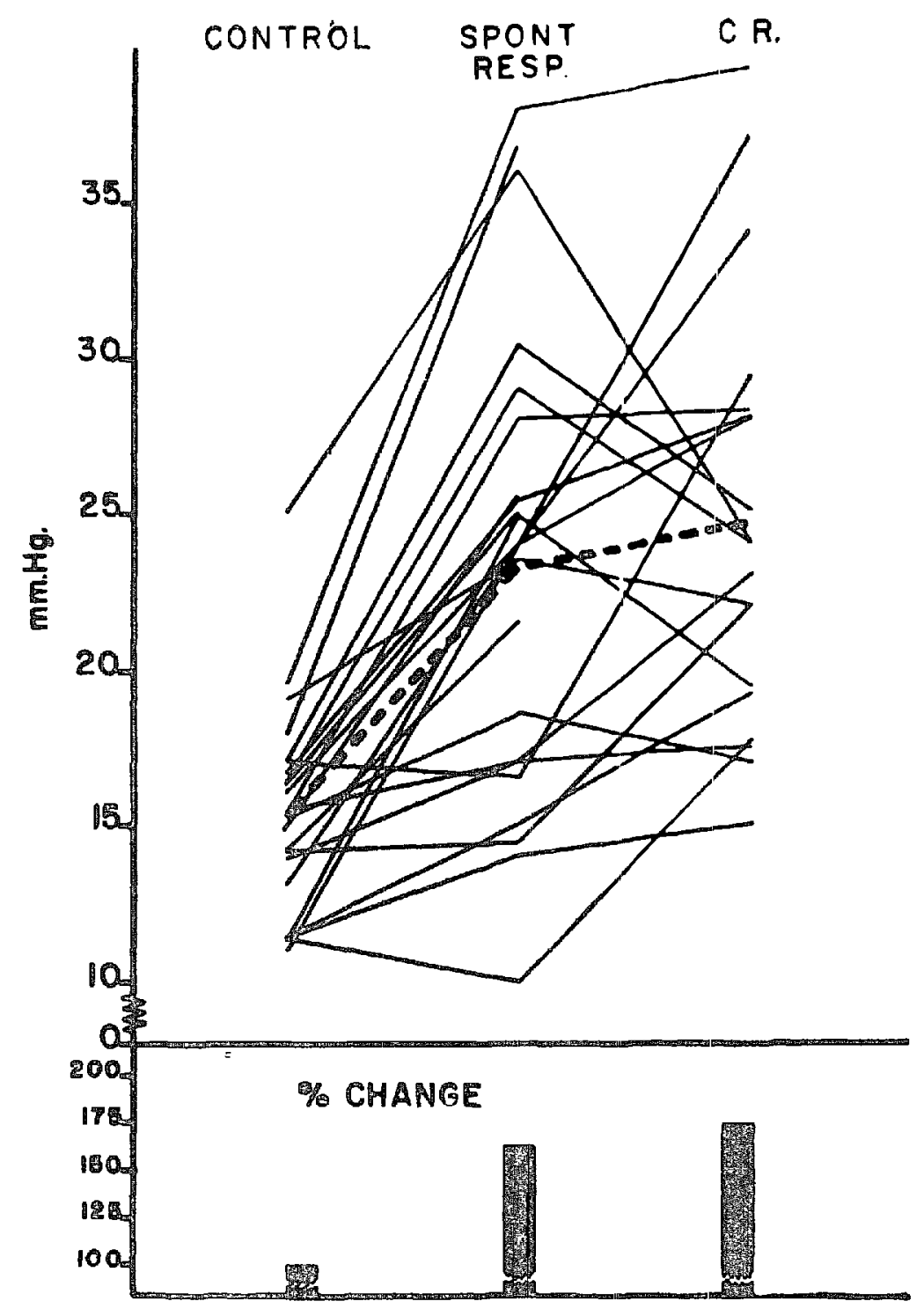

Figure 8. Mean pulmonary blood pressure.

In one instance acetylcholine was injected into the pulmonary artery via the cardiac catheter both with the patient awake and resting and after anaesthesia had been induced. Although this produced a fall in peripheral pressure, it did not influence the mean pulmonary pressure or pulmonary resistance. This does not necessarily exclude a theory of pulmonary vasoconstriction since the effect of ether may have predominated over the effect of acetylcholine.

Consequently, it was then decided to measure wedge pressure in a number of experiments. Table I shows the pulmonary artery pressure and the portions thereof due to pulmonary arteriolar resistance and resistance to left auricular filling. It shows the pulmonary hypertension of similar magnitude both with the patient intubated and not. Column 5 shows values obtained after extubation and discontinuation of ether. These figures show that the pressure does not return to control values even though the patients were almost awake. Column 4 illustrates the various pressures while respiration is being controlled. Table II shows the total pulmonary resistances and the two components of it and would indicate the total resistance is more a function of arteriolar resistance than left heart resistance; except during controlled respiration when these values 


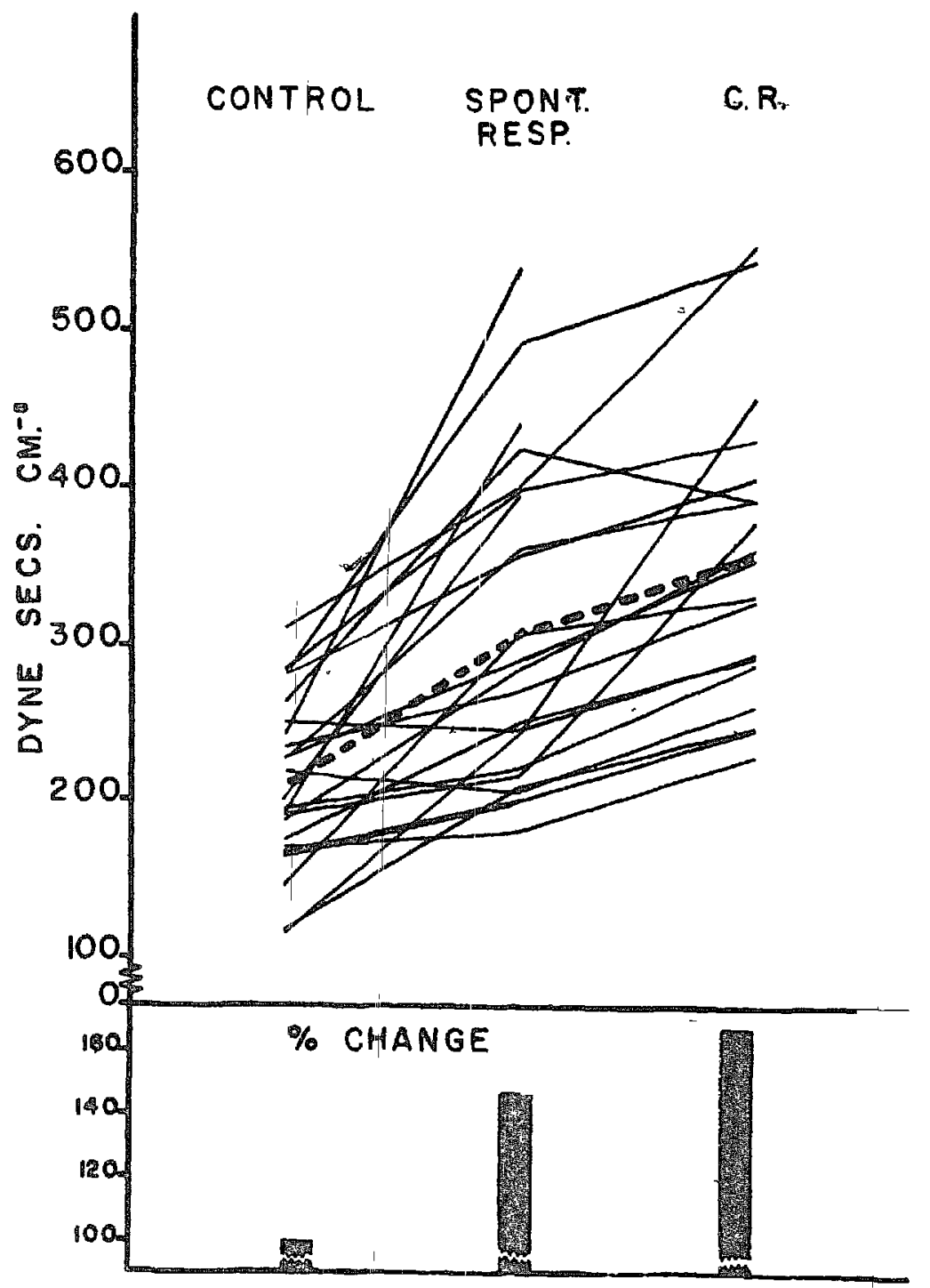

FigURE 9. Total pulmonary resistance.

TABLE I

Components of Pulmonary Blood Pressure

\begin{tabular}{|c|c|c|c|c|c|}
\hline & Control & $\begin{array}{l}\text { Spont. resp. } \\
\text { without tube }\end{array}$ & $\begin{array}{l}\text { Spont. resp. } \\
\text { with tube }\end{array}$ & $\begin{array}{c}\text { Eisten } \\
\text { ventitator }\end{array}$ & Extubated \\
\hline $\begin{array}{l}\text { Arterial Pressure } \\
\text { Venous Pressure }\end{array}$ & $\begin{array}{l}7.1 \\
8.2 \\
\end{array}$ & $\begin{array}{l}1.3 .5 \\
11.2\end{array}$ & $\begin{array}{l}13.1 \\
12.3 \\
\end{array}$ & $\begin{array}{r}6.5 \\
17.2 \\
\end{array}$ & $\begin{array}{l}10.2 \\
12.7 \\
\end{array}$ \\
\hline $\begin{array}{l}\text { Total Pulmonary } \\
\text { Pressure }\end{array}$ & 15.3 & 24.6 & 25.4 & 2.3 .7 & 22.9 \\
\hline
\end{tabular}

TABLE II

Cómponents of Total Pulmonary Resistance

\begin{tabular}{|c|c|c|c|c|c|}
\hline & Control & $\begin{array}{l}\text { Spont. resp. } \\
\text { without tube }\end{array}$ & $\begin{array}{l}\text { Spont. resp. } \\
\text { with tube }\end{array}$ & $\begin{array}{l}\text { Etsten } \\
\text { venitilator }\end{array}$ & Extubated \\
\hline \multirow{3}{*}{$\begin{array}{l}\text { Vascular Resistance } \\
\text { Lt. Atrial Resis- } \\
\text { tance (Venous) } \\
\text { Total Pulmonary } \\
\text { Resistance }\end{array}$} & 102.6 & 160.7 & 149.4 & 96.3 & 109.3 \\
\hline & 108.1 & 135.7 & 179.6 & $2.52^{\circ} .3$ & 138.6 \\
\hline & 211.0 & 297.7 & 301.0 & 349.0 & 248.0 \\
\hline
\end{tabular}


were reversed and left auricular resistance vastly increased. This occurred despite the fact that no positive intrathoracic pressure was allowed to persist during the expiratory pause (Fig. 1). This is further illustrated in Table III, which shows percentage changes for the components of total pulmonary resistance.

TABLE III

Percentage Changes in Pulmoyary Resistance

\begin{tabular}{lccccc}
\hline & Control & $\begin{array}{c}\text { Spont. resp. } \\
\text { without tube }\end{array}$ & $\begin{array}{c}\text { Spont. resp. } \\
\text { with tube }\end{array}$ & $\begin{array}{c}\text { Eisten } \\
\text { ven:ilator }\end{array}$ & Extubated \\
\hline $\begin{array}{l}\text { Pulmonary Vascular } \\
\text { Resistance }\end{array}$ & 100 & 157 & 146 & 93 & 107 \\
$\begin{array}{l}\text { Lt. Atrial } \\
\quad \text { Resistance }\end{array}$ & 100 & 127 & 139 & 232 & 128 \\
Total & 100 & 141 & 143 & 65 & 117 \\
\hline
\end{tabular}

\section{Other Determinations}

Blood gas and $\mathrm{pH}$ studies done with each output determination on the first 6 subjects were all within the normal range. Oxygen saturation was 100 per cent in each case.

Johnson had found an elevated total pulmonary resistance under both light and deep ether anaesthesia and in those having "Narkotal"-curare anaesthesia. Only those under "Narkotal" anaesthesia alone showed no increase in pulmonary artery pressure or total pulmonary resistance. Since the latter had not been intubated, the last 7 experiments in the present series were done first without intubation to see if intubation itself had any effect on the pulmonary pressure. The 7 subjects showed an initial drop in pulmonary artery pressure after induction with thiopental but as the ether was increased and the anaesthesia reached the levels obtained in the previous experiments, pulmonary artery pressure gradually rose to the level seen previously.

In the 3 other subjects who received nitrous oxide-oxygen with a supplemental intravenous thiopental drip, there occurred also a pulmonary hypertension and increased total pulmonary resistance. These patients were intubated. From these results and the results obtained by Johnson, it would seem that both ether and endotracheal intubation produced an increased total pulmonary resistance.

When the role on total pulmonary resistance of the anaesthetic circuit was studied, it was found that there was no change in the resting level of pulmonary artery pressure in each case, as the awake subjects breathed through the anaesthetic circuit.

\section{Summary and Conclusions}

Changes in the peripheral circulation under light ether anaesthesia were much less dramatic then in the pulmonary circulation. The only changes observed were in a reduction of the mean systemic blood pressure and of the stroke volume. Central blood volume was decreased only during spontaneous respiration. Changes in the pulmonary circulation, on the other hand, were quite remarkable in that both mean pulmonary artery blood pressure and total pulmonary resistance rose as ether anaesthesia became established before 
intubation, but a further rise occurred after the tube had been inserted. Thereafter a further rise was noted when respiration was manually controlled. This occurred despite the fact that there remained no positive airway pressure during the expiratory pause. Following extubation the pulmonary artery pressure and total 'resistance did not return to normal unitil the subjects were practically awake. Results were not influenced by resistance in the anaesthetic circuit.

From wedge pressure studies it would appear that the increase in total pulmonary resistance on spontaneous respiration is in a larger measure due to the vascular component, whereas during controlled respiration left atrial resistance plays the predominant role.

At this stage of the investigation one is somewhat reluctant to draw practical conclusions from these findings. Further studies must be carried out to determine what effects other anaesthetic agents have on pulmonary circulation. From previous studies it would appear that both halothane and azeotropic halothane-ether behave in a similar fashion but other agents and the role of depth of anaesthesia and of the relaxant drugs must be evaluated. Further studies are also needed with different patterns of ventilation before final conclusions can be drawn. However, the thought must naturally occur that, although the increased total pulmonary resistance observed in these studies may not be of great practical significance in healthy individuals, the strain imposed on the right heart by this increased resistance may become a significant factor indeed in patients with poor cardiac reserve.

\section{ACKNOWLEDGMENT}

Dr. Donaldson was a Research Fellow in the Department of Anaesthesia during the year 1959-60. This Fellowship was supported by Messrs. Abbott Laboratories Limited; Ayerst McKenna and Harrison Limited; Burroughs Wellcome and Company Limited; and Parke, Davis and Company.

\section{R'́SUMÉ}

Nous avons fait des expériences sur 16 jeunes volontaires masculins pour étudier les modifications de la dynamique circulatoire, plus particulièrement la circulation pulmonaire, au cours de l'anesthésie légère à l'éther. Nous avons mesuré et enregistré par moyens directs le débit cardiaque, la pression artérielle périphérique, l'électrocardiogramme et la pression dans les voies respiratoires et nous avons calculé la résistance périphérique totale et la résistancé pulmonaire, la vitesse moyenne de circulation, le volume sanguin central et le volume systolique. Le niveau d'anesthésie a été maintenu constant à l'aide de l'électroencéphalogramme. Au cours de certaines expériences, nous avons même étudié le pourcentage de saturation en oxygène du sang artériel, le $\mathrm{PaCO}_{2}$ et $\mathrm{pH}$. Toutes ces analyses ont été faites, le malade étañ éveillé, respirant spontanément après l'intubation mais aidé par le ventilateur manuel Etsten, et de nouveau après l'extubation. Au cours d'un certain nombre d'expériences, nous avons également fạit des prélevés alors que les malades respiraient 
spontanément avec un masque seulement sur la face. Nous avons mesuré les pressions dans les segments pour étudier la differénce entre les composantes artérielles et veineuses de la pression et de la résistance pulmonaire totale.

A la suite de ces études, nous avons constaté que les seuls changements sur la circulation périphérique, au cours de l'anesthésie légère à l'éther, consistaient en une diminution de la moyenne de la pression sanguine systolique et du volume systolique durant toutes les phases des expériences et du volume sanguin central durant la respiration spontanée. Les changements les plus notoires, d'autre part, ont été observés sur la circulation pulmonaire et ont consisté en ce que la moyenne de la pression sanguine dans l'artère pulmonaire et la résistance pulmonaire totale se sont élevées toutes les deux durant l'induction de l'anesthésie à l'éther, elles se sont élevées encore davantage après l'intubation et encore davantage au cours de la respịration contrôlée. Après l'extubation, la pression dans l'artère pulmonaire et la résistance ne revenaient à la normale seulement lorsque les malades étaient pratiquement réveillés. Grâce à des expériences de contrôle, noùs avons pu établir que ces résultats n'étaient pas influencés par la résistance dans les appareils à anesthésie. L'étude de la pression dans les segments laisse comprendre que l'au:gmentation de la résistance pulmonaire totale, au cours de la respiration sponlanée, était due davantage aux composantes vasculaires car durant la respiration contrôlée, la résistance de l'oreillette gauche jouait le principal rôle.

\section{REFERENCES}

1. Johrson, S. R. The Effect of Some Anaesthetic Agents on the Circulation in Man. Acta Chirurg. Scandinav. Supp. 158.

2. Sancetta, S. M.; Lynn, R. B.; Simeone, F. A.; \& Scott, R. W. Studies of Haemodynamic Changes in Humans Following Induction of Low and High Spinal Anaesthesia. Circulation $6,(4): 559-571$ (1952).

3. Lynv, R. B.; Sancetta, S. M.; Simeone, F. A.; \& Sccitt, R. W. Observations on the Circulation in High Spinal Anaesthesia. Surgery. 32 (2): 195-213 (1952).

4. L1, T.-H., \& ETsten, B. Effect of Cyclopropane Anesthesia on Cardiac Output and Related Haemodynamics in Man. Anesthesiology. 18 (1): 15-32 (1957).

5. Wyant, G. M.; Merriman, J. E.; Kilduff, C. J.; \& Thomas, E. T. The Cardiovascular Effects of Halothane. Canad. Anaesth. Soc. J. 5 (4): 38-t-402 (1958).

6. Wyant, G. M.; Merrimian, J. E.; Harland, J. H.; \& Donaldson, H. V. The Cardiovascular Effects of Azeotropic Halothane-Ether. Canad. Anaesth. Soc. J. 7 (2): $91-99$ (1960).

7. Merriman, J. E.; Wyant, G. M.; Bray, G.; \& McGeachy, W. Serial Cardiac Output Determinations in Man. Canad. Anaesth. Soc. J. 5 (4): 375-383 (1958).

8. Hellems, H. K., Haynes, F. W., \& Dexter, L. Pulmonary Capillary Pressure in Man. J. Appl. Physiol. 2 (1): 24-29 (1949).

9. Cathcart, R. T.; Nealson, T. F., JR.; Fraimow, W.; Hamptom, L. J.; \& Gibbon, J. H., JR. Cardiac Output Under General Anaesthesia: Effect of Mean Endotracheal Pressure. Ann. Surg. 148 (3): 488-497 (1958).

10. Etsten, B., \& Li, T. H. Hemodynamic Changes During Thiopental Anesthesia in Humans: Cardiac Output, Stroke Volume, Total Peripheral Resistance, and Intrathoracic Blood Volume. J. Clin. Invest. 84: 500 (1955).

11. Lee, G. De J.; Churchill-Davidson, H ; Miles, B. E.; \& De Wardener, H. E. Circulatory Effects of Prolonged Light Anaesthesia In Man. Clin. Sc. 12: 169 (1953).

12. Shackman, R., Graber, I. G., \& Melrose, D. G. Haemodynamics of Surgical Patient under General Anaesthesia. Brit. J. Surg. 40;193 (1952). 